\title{
PENERAPAN ASAS ULTIMUM REMEDIUM DALAM RANGKA PERLINDUNGAN ANAK PECANDU NARKOTIKA
}

\author{
Afni Zahra1', RB. Sularto² \\ PROGRAM STUDI MAGISTER ILMU HUKUM \\ FAKULTAS HUKUM UNIVERSITAS DIPONEGORO \\ sularto_rb@yahoo.com
}

\begin{abstract}
ABSTRAK
Anak merupakan bagian dari generasi muda sebagai salah satu sumber daya manusia yang merupakan potensi dan penerus cita-cita perjuangan bangsa di masa yang akan datang, yang memiliki peran strategis dan mempunyai ciri dan sifat khusus. Adanya putusan pengadilan anak yang cenderung menjatuhkan pidana penjara dari pada tindakan terhadap anak yang melakukan tindak pidana, sebenarnya tidak sesuai dengan filosofi dari pemidanaan dalam hukum pidana anak. Dengan meningkatnya jumlah penyalahguna narkotika khususnya pecandu yang menjerat anak di bawah umur membuat mereka harus berurusan dengan proses peradilan yang panjang. Sanksi pidana dijadikan sarana pembalasan atas perbuatan yang dilakukan oleh anak. Sanksi pidana harusnya menjadi suatu (ultimum remedium) obat terakhir apabila sarana lain dirasa tidak mampu menanggulangi. Anak yang terjerat kasus hukum terutama disebabkan penyalahgunaan narkotika tidak sepenuhnya adalah pelaku dan penjahat yang harus di hukum layaknya orang dewasa, mereka juga merupakan korban yang belum dapat bertanggungjawab seluruhnya atas perbuatannya maka perlu adanya perlindungan hukum terhadap anak pecandu narkotika. Selain itu asas ultimum remedium menjadi sangat penting karena pidana seharusnya menjadi pilihan terakhir dalam mengembalikan kondisi anak menjadi lebih baik. Penelitian ini bertujuan untuk mengetahui sejauh mana negara ini memiliki payung hukum dalam melindungi anak penyalahgunaan narkotika dan mengetahui optimalisasi penerapan asas ultimum remedium terhadap pecandu narkotika yang dilakukan oleh anak. Dalam mencapai tujuan penelitian, maka metode penelitian yang digunakan adalah metode normatif dengan pendekatan deskriptif analitis. Metode pengumpulan data yang dipakai adalah kepustakaan baik secara hukum maupun teori yang dianalisis dan dideskripsikan untuk memberikan gambaran yang konkrit. Hasil penelitian dapat disimpulkan, bahwa Undang - Undang Nomor 35 Tahun 2014 tentang Perlindungan Anak telah mengatur perlindungan itu meliputi upaya pengawasan, pencegahan, perawatan dan rehabilitasi yang dilakukan oleh pemerintah dan masyarakat. Penerapan asas ultimum remedium terhadap anak menjadi upaya terakhir dengan adanya ketentuan UU No. 11 Tahun 2012 tentang Sistem Peradilan Pidana Anak yang mewajibkan setiap anak yang berhadapan dengan hukum untuk dilakukan upaya diversi sebelum dilakukan upaya peradilan dan penjatuhan pidananya pun harus bersifat non- custodial.
\end{abstract}

\section{Kata Kunci: Asas Ultimum Remedium; Pecandu Narkotika; Perlindungan Anak}

\footnotetext{
${ }^{1}$ Mahasiswa Program Studi Magister IImu Hukum UNDIP

2 Penulis Kedua, Penulis Koresponden
} 


\section{PENDAHULUAN}

Pada hakikatnya sistem peradilan pidana anak yaitu mengutamakan perlindungan dan rehabilitasi terhadap pelaku anak (emphasized the rehabilitation of youthful offender) sebagai orang yang masih mempunyai sejumlah keterbatasan dibandingkan dengan orang dewasa. Anak memerlukan perlindungan dari negara dan masyarakat dalam jangka waktu ke depan yang masih panjang. Terhadap anak yang terlanjur menjadi pelaku tindak pidana diperlukan strategi sistem peradilan pidana yaitu mengupayakan seminimal mungkin intervensi sistem peradilan pidana. $^{3}$

Sanksi yang tajam dalam hukum pidana ini membedakannya dari lapangan hukum lainnya. Hukum pidana sengaja mengenakan penderitaan dalam mempertahankan norma-norma yang diakui dalam hukum. Inilah sebabnya mengapa hukum pidana harus dianggap sebagai ultimum remedium yakni "obat terakhir" apabila sanksi pada cabng hukum lainnya tidak mampu atau dianggap tidak mempan. Oleh karena itu penggunaannya harus dibatasi. Kalau masih ada jalan lain janganlah menggunakan hukum pidana. ${ }^{4}$

Mengacu data Komisi Perlindungan Anak Indonesia (KPAI) mencatat terkait tindak pidana

\footnotetext{
${ }^{3}$ Marlina, Pengantar Konsep Diversi Dan Restorative J ustice Dalam Hukum Pidana, (Medan: USU Press, 2010), hal. 1.

${ }^{4}$ Sudarto, Hukum Pidana I, (Semarang: Yayasan Sudarto, 1990), hal. 13.
}

penyalahgunaan narkoba, selama kurun waktu 2011 hingga 2014 terjadi peningkatan signifikan jumlah anak yang terjerat narkoba hingga mencapai hampir 400\%. Hal ini cukup menggambarkan penyalahgunaan narkoba pada anak-anak sudah sangat mengkhawatirkan. Sejalan dengan hasil penelitian yang telah dilakukan oleh pihak BNN yang menyebutkan bahwa pada tahun 2014 yang lalu, sebanyak 33 persen pengguna narkoba berada pada usia pelajar dan mahasiswa. Tidak hanya sebagai pemakai, tapi juga pengedar. ${ }^{5}$ Pengguna remaja yang berusia 12-21 tahun ditaksir sekitar 14.000 orang dari jumlah remaja di Indonesia sekitar 70 juta orang. Hal ini karena dipengaruhi kerentanan remaja terhadap faktor lingkungan. Kondisi mental remaja yang biasanya ingin tahu dan labil, jika ditambah pergaulan yang tidak sehat, bisa menjerumuskan mereka ke praktik penyalahgunaan napza. ${ }^{6}$

Seharusnya anak korban penyalahgunaan narkotika tidak mendapat pidana kurungan di Lapas. Sesuai dengan amanat Undang-Undang No. 35 Tahun 2014 tentang Perlindungan Anak, selayaknya anak mendapat rehabilitasi pada lembaga dan institusi yang telah ditunjuk oleh pemerintah. Hal ini sesuai dengan pasal 67 yang berisi:

\footnotetext{
${ }^{5}$ http://www.kpai.go.id/berita/kpai-jumlah-anak-korbannarkoba-terus-bertambah. Diakses tanggal 30 September 2016.

${ }^{6}$ http://regional.kompas.com/read/2013/03/07/03184385/Peng guna.Narkoba.di.Kalangan.Remaja.Meningkat.Diakses tanggal 30 September 2016.
} 
"Perlindungan khusus bagi Anak yang menjadi korban penyalahgunaan narkotika, alkohol, psikotropika, dan zat adiktif lainnya sebagaimana dimaksud dalam Pasal 59 ayat (2) huruf e dan Anak yang terlibat dalam produksi dan distribusinya dilakukan melalui upaya pengawasan, pencegahan, perawatan, dan rehabilitasi."

Salah satu bentuk penanganan terhadap anak yang berkonflik dengan hukum dalam hal ini penyalahgunaan narkotika diatur di dalam Pasal 64 Huruf G Undang-Undang Nomor 35 Tahun 2014 tentang Perlindungan Anak yang menyatakan, bahwa;

" Penghindaran dari penangkapan, penahanan atau penjara, kecuali sebagai upaya terakhir dan dalam waktu yang paling singkat."

Dalam Undang- Undang sebelumnya juga ditegaskan dalam Pasal 16 Ayat (3) UndangUndang Nomor 23 Tahun 2003 tentang Perlindungan Anak, bahwa;

" Penangkapan, penahanan, atau tindak pidana penjara anak hanya dilakukan apabila sesuai dengan hukum yang berlaku dan hanya dapat dilakukan sebagai upaya terakhir."

Pasal diatas sesuai dengan Convention of The Right of The Child yang telah diratifikasi oleh Pemerintah Indonesia dengan Keputusan Presiden Nomor 36 tahun 1990 pada Pasal 37 huruf (b) yang menyatakan bahwa:

" Negara-negara Pihak harus menjamin bahwa tidak seorang anak pun dapat dirampas kebebasannya secara melanggar hukum atau dengan sewenang-wenang. Penangkapan, penahanan, atau pemenjaraan seorang anak harus sesuai dengan Undang-Undang, dan harus digunakan hanya sebagai upaya jalan lain terakhir dan untuk jangka waktu terpendek yang tepat."

Pasal 16 Ayat (3) Undang-Undang Nomor 23 Tahun 2002 jo Pasal 64 Huruf G Undang-Undang Nomor 35 Tahun 2014 Tentang Perlindungan Anak serta Pasal 37 huruf (b) Keputusan Presiden Nomor 36 tahun 1990 di atas merupakan bentuk adopsi dari asas ultimum remedium/the last resort principle, yang maksudnya adalah untuk melindungi dan mengayomi anak yang berkonflik dengan hukum agar anak dapat menyongsong masa depannya yang masih panjang serta memberi kesempatan kepada anak agar melalui pembinaan terlebih dahulu bukan penjatuhan pidana, anak akan memperoleh jati dirinya untuk menjadi manusia yang mandiri, bertanggung jawab dan berguna bagi diri sendiri, keluarga, masyarakat, bangsa, dan negara.

Berdasarkan latar belakang yang telah diuraikan di atas, maka penulis merasa perlu mengkaji dan meneliti lebih dalam mengenai asas ultimum remedium terhadap perlindungan anak dengan judul "Penerapan Asas Ultimum Remedium dalam Rangka Perlindungan Anak Pecandu Narkotika" 
Beberapa pokok permasalahan yang akan dibahas dalam penulisan tesis ini, yakni sebagai berikut:

1. Bagaimanakah perlindungan anak pecandu narkotika dengan menggunakan kebijakan hukum pidana yang ada?

2. Bagaimana penerapan asas ultimum remedium terhadap anak pecandu narkotika?

\section{METODE PENELITIAN}

Metode penelitian yang digunakan dalam penulisan tesis ini yaitu yuridis normatif yaitu suatu penelitian hukum yang dilakukan dengan cara meneliti bahan pustaka. Pendekatan yuridis adalah suatu pendekatan yang mengacu pada hukum dan peraturan perundang-undangan yang berlaku.

Spesifikasi penelitian yang digunakan dalam penelitian ini adalah deskriptif analitis. Deskriptif yaitu penelitian yang menggambarkan objek penelitian berdasarkan fakta yang sebagaimana adanya, dilaksanakan secara sistematis, kronologis dan berdasarkan kaidah ilmiah. Adapun analitis maksudnya dikaitkan dengan teori-teori hukum yang ada dan atau peraturan perundang-undangan yang berkaitan dengan objek yang diteliti.

\section{PEMBAHASAN}

\section{A. Perlindungan anak pecandu narkotika dengan menggunakan kebijakan hukum pidana yang ada}

Perlindungan hukum terhadap anak yang diatur dalam Undang - Undang No. 35 Tahun 2014 tentang Perlindungan Anak (Pasal 67) dilakukan melalui upaya pengawasan, pencegahan, perawatan dan rehabilitasi oleh pemerintah dan masyarakat. Adapun perlindungan hukum bagi anak penyalahguna narkotika ini diberikan karena anak harus tetap dianggap hanya sebagai korban. Anak penyalahguna narkotika, bukanlah penjahat sesungguhnya. Oleh sebab itu perlu perlindungan hukum agar anak dapat diawasi, dicegah sehingga tidak terlibat di dalam penyalahgunaan narkotika. Anak juga perlu perawatan dan rehabilitasi apabila sudah terlanjur terlibat atau dilibatkan dalam penyalahgunaan narkotika. ${ }^{7}$

Upaya pengawasan dan pencegahan tersebut termasuk pada upaya preventif (pencegahan) artinya sebelum terjadinya penyalahgunaan tersebut maka si anak harus telah diawasi agar tidak sampai terjerumus. Upaya ini lebih mudah dilakukan dan tidak memakan biaya yang begitu besar bila dibandingkan dengan upaya penanggulangan perawatan dan rehabilitasi termasuk dalam upaya represif. 8

Pencegahan terhadap pelibatan anak di bawah umur dalam penyalahgunaan dan peredaran gelap narkoba ( pasal 52 ayat (2) c Undang Undang Narkotika ). Sedangkan upaya represif adalah lebih kepada upaya dalam hal

\footnotetext{
${ }^{7}$ Beni harmoni Harefa, Kapita Selekta Perlindungan Hukum bagi Anak, (Yogyakarta: CV Budi Utama, 2016), hal. 16.

${ }^{8}$ Ibid., hal. 17.
} 
penyalahgunaan narkoba yang dilakukan bila kejahatan itu sudah terjadi dengan jalan melakukan penindakan. Tindakan yang dilakukan meliputi perawatan dan rehabilitasi. Para pecandu narkoba yang telah menempuh proses pengobatan dan sedang dalam mengembalikan kondisinya supaya normal kembali sehingga dapat hidup dengan wajar dan normal dengan masyarkat, sangat memerlukan rehabilitas. Rehabilitasi ini memerlukan waktu yang sangat lama dan memakan biaya yang lumayan besar dibandingkan dengan pencegahan. Pihak pihak yang turut membantu upaya rehabilitasi ini meliputi dokter, psikiater, guru, tokoh agama dan terlebih khusus keluarga korban. ${ }^{9}$

Sejak berlakunya Undang - Undang Nomor 11 Tahun 2012 tentang Sistem Peradilan Pidana Anak ( UU SPPA ), penyelesaian perkara pidana anak diwajibkan melalui diversi. Menurut Jack E. Bynum dalam bukunya delinquency a sociological approach, memberikan pengertian diversi yaitu divertion is an attempt to divert or channel out, youthful offenders from the juvenile justice system (diversi adalah sebuah tindakan atau perlakuan untuk mengalihkan atau menempatkan pelaku tindak pidana anak keluar dari sistem peradilan). ${ }^{10}$ Melihat pentingnya diversi untuk menghindari anak

\footnotetext{
${ }^{9}$ Beni harmoni Harefa., loc., cit.

${ }^{10}$ Marlina, Konsep Diversi dan Restorative Jusitca Dalam UU No 11 Tahun 2012 tentang Sistem Peradilan Pidana Anak, makalah disampaikan pada workshop tentang Restorative Justice dalam Perspektif UU Sistem Peradilan Anak dan Kearifan Lokal Masyarakat Nias, Hotel Nasional, Gunungsitoli, 21 Mei 2013, hlm. 1.
}

dari dampak negatif peradilan pidana, maka diversi menjadi salah satu upaya perlindungan hukum bagi anak. Diversi mempunyai peranan penting dalam memberikan perlindungan atas hak - hak asasi anak. ${ }^{11}$

Adanya perlindunga terhadap anak juga di atur dalam Undang-Undang Nomor 31 Tahun 2014 tantang Perubahan atas Undang-Undang Nomor 13 Tahun 2006 tentang Perlindungan Saksi dan Korban. Dalam hal ini anak penyalahguna narkotika tidak hanya sebagai pelaku tetapi juga sebagai korban yang memiliki hak dan perlindungan tertentu. Perlindungan ini tertuang dalam Pasal 29 A, Pasal 5 dan 7A.

\section{B. Penerapan asas ultimum remedium di dalam penyalahgunaan (pecandu) narkotika oleh anak}

1. Ketentuan Sanksi Pidana Bagi Anak dalam Undang-Undang Pengadilan Anak dan atau Undang-Undang Sistem Peradilan Pidana Anak

Sebelum dijatuhkannya pidana terhadap anak ada upaya alternatif yang wajib dilakukan oleh penegak hukum yaitu diversi, yang terdapat dalam Pasal 5 dan Pasal 7 UU No. 11 Tahun 2012 Tentang Sistem Peradilan Pidana Anak.

11 Beni harmoni Harefa, "Diversi Sebagai Perlindungan Hukum Terhadap Hak Asasi Anak Dalam Sistem Peradilan Pidana Anak di Indonesia", dalam Taufik El Rahman, dkk (ed.), Aktualisasi Hukum Kontemporer. Respons Atas Persoalan Hukum Nasional dan Internasional, (Yogyakarta: Genta Press, 2015), hal. 363. 
Apabila proses dan hasil kesepakatan diversi tercapai maka anak tidak perlu melanjutkan perkara ke tahap berikutnya, dengan demikian dapat dimintakan penetapan pengadilan. Proses peradilan pidana anak hanya akan dilanjutkan terhadap anak apabila proses diversi tidak menghasilkan kesepakatan atau kesepakatan diversi tidak dilaksanakan (Pasal 13).

Adapun dalam Undang-Undang Nomor 11 Tahun 2012 tentang Sistem Peradilan Pidana Anak, Ketentuan Pidana bagi anak telah mengalami penyempurnaan lebih lengkap dibanding UndangUndang Nomor 3 Tahun 1997 tentang Pengadilan Anak, dan secara tegas diatur dalam Bab $\mathrm{V}$ tentang Pidana dan Tindakan pada Pasal 69 sampai dengan Pasal 83. Pada bagian awal sudah secara tegas dalam Pasal 69 ayat(1) disebutkan bahwa Anak hanya dapat dijatuhi pidana atau dikenai tindakan berdasarkan ketentuan dalam UndangUndang ini. Disamping itu juga terdapat pembatasan usia anak dalam pemidanaan pada Pasal 69 (2) yang menyebutkan bahwa Anak yang belum berusia 14 (empat belas) tahun hanya dapat dikenai tindakan. ${ }^{12}$

Bahkan dalam penjatuhan pidana atau mengenakan tindakan terhadap anak diatur tentang dasar pertimbangan bagi hakim, yang dirumuskan pada Pasal 70, yang menyebutkan "Ringannya perbuatan, keadaan pribadi Anak, atau keadaan pada waktu dilakukan perbuatan atau yang terjadi kemudian dapat dijadikan dasar pertimbangan hakim untuk tidak menjatuhkan pidana atau mengenakan tindakan dengan mempertimbangkan segi keadilan dan kemanusiaan."13

2. Ketentuan Sanksi Pidana bagi Anak dalam Undang-Undang Narkotika

Undang-Undang Narkotika tidak secara khusus mengatur tentang stelsel sanksi bagi anak maka akan dilihat bagaimana berlakunya stelsel sanksi dalam Undang-Undang Narkotika tersebut terhadap anak. Meskipun, dalam Undang-Undang Narkotika juga terdapat beberapa pasal pengecualian yang khusus diberlakukan terhadap mereka yang belum cukup umur. Sehingga berlakunya stelsel sanksi dalam Undang-Undang Narkotika terhadap anak harus diberlakukan juga Undang-Undang Pengadilan Anak sebagai ketentuan khusus yang diterapkan terhadap anak.

Untuk memberikan gambaran yang lebih utuh tentang bagaimana stelsel sanksi bagi anak dalam Undang-Undang Narkotika berikut ini akan disajikan ketentuan-ketentuan pidana dalam Undang-Undang Narkotika (Undang-Undang Nomor 22 tahun 1997). Penyalahgunaan narkotika

${ }^{12}$ Koesno Adi, Diversi Tindak Pidana Narkotika Anak, (Malang: Setara Press, 2015), hal. 18. 
dalam Undang-Undang Narkotika diatur dalam Pasal 85 , yang menyatakan: ${ }^{14}$

Barang siapa tanpa hak dan melawan hukum :

a) Menggunakan narkotika Golongan I bagi diri sendiri, dipidana dengan pidana penjara paling lama 4 (empat) tahun;

b) Menggunakan narkotika Golongan II bagi diri sendiri, dipidana dengan pidana penjara palin lama 2 (dua) tahun;

c) Menggunakan narkotika Golongan III bagi diri sendiri, dipidana dengan pidana penjara paling lama 1 (satu) tahun.

Berdasarkan ketentuan Pasal 85 UndangUndang Narkotika tersebut di atas, maka penyalahgunaan narkotika dalam konteks ini mengandung makna bahwa penyalahgunaan narkotika yang dilakukan dengan tanpa hak dan melawan hukum yang ditujukan bagi diri sendiri. ${ }^{15}$

Dengan formulasi seperti tersebut di atas, persoalannya adalah, bagaimana apabila yang melakukan pelanggaran terhadap ketentuan Pasal 85 Undang-Undang Narkotika adalah orang yang belum cukup umur? Dengan merujuk ketentuan Pasal 85 Undang-Undang Narkotika jo Pasal 22

${ }^{14}$ Koesno Adi., ibid, hal. 23

15 Koesno Adi., ibid, hal. 23-24.
Undang-Undang Pengadilan Anak dapat dikemukakan, bahwa meskipun dalam Pasal 85 Undang-Undang Narkotika pidana yang harus dijatuhkan hakim hanyalah pidana penjara, namum apabila orang yang melakukan pelanggaran tersebut kualifikasinya masih belum cukup umur, maka berlakulah ketentuan Pasal 22 UndangUndang Pengadilan Anak. ${ }^{16}$

Dengan demikian, apabila ada orang yang belum cukup umur melakukan tindak pidana sebagaimana dimaksud dalam Pasal 85 UndangUndang Narkotika, maka pidana yang dapat dijatuhkan oleh hakim tidak hanya terbatas pada pidana penjara sebagaimana dirumuskan dalam Pasal 85 Undang-Undang Narkotika, tetapi hakim dapat juga menjatuhkan putusan sebagaimana diatur dalam Pasal 22 Undang-Undang Pengadilan Anak. Dengan demikian terhadap penyalahgunaan narkotika yang dilakukan oleh orang yang belum cukup umur, maka berdasarkan ketentuan Pasal 85 UndangUndang Narkotikajo Pasal 22 UndangUndang Pengadilan Anak, menyatakan bahwa Terhadap Anak Nakal hanya dapat dijatuhkan pidana atau tindakan yang ditentukan dalam undang-undang ini. Dengan demikian dalam penerapan ketentuan tersebut berlaku asas lex specialis derogat legi generalis. ${ }^{17}$

16 Koesno Adi., loc., cit.
17 Koesno Adi., loc., cit. 
Dari kasus yang muncul, ada kalanya Anak berada dalam status saksi dan/atau korban sehingga Anak Korban dan/atau Anak Saksi juga diatur dalam Undang-Undang SPPA. Khusus mengenai sanksi terhadap Anak ditentukan berdasarkan perbedaan umur Anak, yaitu bagi Anak yang masih berumur kurang dari 12 (dua belas) tahun hanya dikenai tindakan, sedangkan bagi Anak yang telah mencapai umur 12 (dua belas) tahun sampai dengan 18 (delapan belas) tahun dapat dijatuhi tindakan dan pidana.

\section{KESIMPULAN}

1. Perlindungan hukum terhadap anak korban penyalahgunaan narkoba telah diatur dalam Peraturan Perundang - Undangan yang berlaku di Negara kita. Perlindungan ini diatur dalam Undang - Undang Nomor 35 Tahun 2014 tentang Perubahan atas Undang - Undang Nomor 23 Tahun 2002 tentang Perlindungan Anak. Khususnya pada pasal 67 ayat ( 1 ) ditentukan adanya perlindungan khusus bagi anak yang menjadi korban penyalahgunaan narkotika, alkohol, psikotropika dan zat adiktif lainnya (napza). Sebagaimana dimaksud dalam Undang - Undang tersebut bahwa pemerintah dan lembaga Negara lainnya berkewajiban dan bertanggung jawab untuk memberikan perlindungan khusus kepada anak salah satunya adalah anak yang menjadi korban penyalahgunaan narkotika, alkohol, psikotropika dan zat adiktif lainnya (napza). Perlindungan itu meliputi upaya pengawasan, pencegahan, perawatan dan reehabilitasi yang dilakukan oleh pemerintah dan masyarakat. Selain itu dalam Undang-Undang Nomor 11 Tahun 2012 tentang Sistem Peradilan Pidana Anak wajib dilakukannya upaya yang diversi menjadi salah satu upaya perlindungan hukum bagi anak. Adanya perlindungan terhadap anak juga di atur dalam Undang-Undang Nomor 31 Tahun 2014 tantang Perubahan atas Undang-Undang Nomor 13 Tahun 2006 tentang Perlindungan Saksi dan Korban yaitu pada Pasal 5 dan $7 \mathrm{~A}$.

2. Asas ultimum remedium terhadap anak yang berkonflik dengan hukum maksudnya adalah dengan menjadikan keseluruhan proses peradilan pidana anak sebagai jalan terakhir. Asas pemidanaan yang dijatuhkan terhadap anak yang berkonflik dengan hukum harusnya mengacu kepada asas kepentingan terbaik bagi anak (the best interest of the child), dimana dalam semua tindakan yang menyangkut anak yang dilakukan oleh pemerintah, masyarakat, badan legislatif, dan badan yudikatif maka kepentingan yang terbaik bagi anak harus menjadi pertimbangan utama. Proses peradilan pidana sejauh mungkin dihindarkan dari anak apabila tidak ada cara lain (ultimum remedium) dan penjatuhan pidananya pun harus bersifat non-custodial, sehingga meminimalisasi adanya dampak negatif dari dijatuhkannya pidana penjara. Hal ini dapat dilihat dari stelsel pidana pada UU SPPA dimana diversi 
menjadi jalan utama sebelum lanjut pada proses peradilan apabila diversi tidak berhasil maka proses peradilan akan dilanjutkan dan pidana hanya dapat dijatuhkan apabila tidak ada jalan lain. UndangUndang Narkotika tidak secara khusus mengatur tentang stelsel sanksi bagi anak, berlakunya stelsel sanksi dalam Undang-Undang Narkotika terhadap anak harus diberlakukan juga Undang-Undang SPPA sebagai ketentuan khusus yang diterapkan terhadap anak. Hal ini sebagai konsekuensi adanya asas lex specialis derogat legi generalis.

\section{SARAN}

1. Hendaknya perlu adanya pengawasan dalam penerapan peraturan perundang-undangan yang berlaku terlebih juga pada peningkatan efektifitas pihak-pihak terkait seperti Komisi Perlindungan Anak yang harus lebih dimaksimalkan agar perlindungan hukum terhadap anak korban penyalahgunaan narkotika dapat tertangani. Terdapat lima pilar dalam upaya perlindungan anak khususnya dari penyalahgunaan narkotika, yakni : orang tua, keluarga, masyarakat, pemerintah dan Negara yang seharusnya dapat memaksimalkan perlindungan terhadap anak dalam penyalahgunaan narkotika.

2. Perlu bagi penegak hukum yang meyelesaikan perkara anak untuk benar-benar memahami asas-asas hukum serta peraturan perundang-undangan yang berkaitan dengan penyelesaian perkara anak sehingga menghasilkan putusan pengadilan yang bijaksana bagi anak yang berkonflik dengan hukum khususnya terhadap penyalahguna (pecandu) narkotika.

\section{DAFTAR PUSTAKA}

Adi, Koesno, 2015, Diversi Tindak Pidana Narkotika Anak, Malang: Setara Press.

Gultom, Maidin, 2008, Perlindungan Hukum Terhadap Anak dalam Sistem Peradilan Pidana Anak di Indonesia, Bandung: Refika Aditama.

Harefa, Beni Harmoni, 2016, Kapita Selekta Perlindungan Hukum bagi Anak, Yogyakarta: CV Budi Utama.

Marlina, 2010, Pengantar Konsep Diversi dan Restroative J ustice dalam Hukum Pidana, Medan: USU Press.

Prakoso, Abintoro, 2013, Pembaruan Sistem Peradilan Pidana Anak, Yogyakarta: Laksbang Grafika.

Siswanto, 2012, Politik Hukum dalam UndangUndang Narkotika (UU No. 35 Tahun 2009), Jakarta: Rineka Cipta.

Sudarto, 1990, Hukum Pidana I. Semarang: Yayasan Sudarto. 
Jurnal Law Reform

Volume 13, Nomor 1, Tahun 2017

\section{Website}

http://www.kpai.go.id/berita/kpai-jumlah-anak-

korban-narkoba-terus-bertambah.

http://regional.kompas.com/read/2013/03/07/03184

385/Pengguna.Narkoba.di.Kalangan.Remaj

a.Meningkat.
Program Studi Magister Ilmu Hukum Fakultas Hukum Universitas Diponegoro 